\begin{tabular}{|c|l|}
\hline Title & Potential of Micranthemum umbrosum for phytofiltration of organic arsenic species from oxic water environment \\
\hline Author(s) & Islam, Md Shariful; Sikder, M. Tajuddin; Kurasaki, Masaaki \\
\hline Citation & $\begin{array}{l}\text { International journal of environmental science and technology, 14(2), 285-290 } \\
\text { https://doi.org/10.1007/313762-016-1142-9 }\end{array}$ \\
\hline Issue Date & 2017-02 \\
\hline Doc URL & http://hdl.handle.net/2115/68391 \\
\hline Rights & The final publication is available at link.springer.com \\
\hline Type & article (author version) \\
\hline File Information & Manuscript - Correctedfinal.pdf \\
\hline
\end{tabular}

Instructions for use 


\title{
Potential of Micranthemum umbrosum for phytofiltration of organic arsenic species from oxic water environment
}

\author{
Md. Shariful Islam ${ }^{1,2}$, M. Tajuddin Sikder ${ }^{1,3}$, M. Kurasaki ${ }^{1,4}$ \\ ${ }^{1}$ Environmental Adaptation Science, Division of Environmental Science Development, Graduate \\ School of Environmental Science, Hokkaido University, Sapporo, Japan \\ 2 Department of Agricultural Chemistry, Patuakhali Science and Technology University, Dumki, \\ Patuakhali, Bangladesh
}

3 Department of Public Health and Informatics, Jahangirnagar University, Savar, Dhaka, Bangladesh 4 Group of Environmental Adaptation Science, Faculty of Environmental Earth Science, Hokkaido University, Sapporo, Japan

\begin{abstract}
Arsenic (As) is a toxic and carcinogenic metalloid that causes various hazards to human health. Phytofiltration is a more eco-friendly and green approach than chemoremediation, or other traditional technologies, for removing As from aquatic environments. Recently, Micranthemum umbrosum was shown as a promising candidate for phytofiltration of inorganic As species. This work examines the potential application of M. umbrosum to phytofiltration of organic As species, such as monomethylarsonic acid (MMAA, CH5AsO3) and dimethylarsinic acid (DMAA, C2H7AsO2), from oxic water environments. M. umbrosum plants were grown in two test concentrations of MMAA and DMAA, or a control, in a hydroponic experiment. After seven days, leaves accumulated $90 \pm 3.2$ and $48 \pm 1.6 \mu \mathrm{g}$ As g-1 from $1 \mu \mathrm{g}$ As mL-1 of water added from MMAA and DMAA, respectively. Bio concentration factor values and translocation factor values were always greater than 1.0, indicating that M. umbrosum was a good As accumulator and that leaves accumulated significantly higher amounts of As than stems and roots. Analysis of macro- and micro-nutrient data showed that M. umbrosum had higher resistance to
\end{abstract}


organic As treatments than the control. These results confirm the potential application of M. umbrosum for phytofiltration of organic As from contaminated oxic water environments.

Key Words: dimethylarsinic acid; monomethylarsonic acid; phytofiltration; plant; water

\section{Introduction}

Arsenic in drinking water is one of the most serious environmental health hazards faced by millions of people in many areas of the world, such as Bangladesh, India, USA, China, Taiwan, Mexico, Argentina, Poland, Canada, Hungary, New Zealand, Japan, and Chile (Knobeloch et al., 2006; Mohan and Pittman, 2007; Kim et al., 2011). Arsenic is highly toxic and can lead to a wide range of health problems, being carcinogenic, mutagenic, and teratogenic (NRC, 1999; Smedley and Kinniburgh, 2002). Arsenic exists in the environment in four oxidation states $(+\mathrm{V}($ arsenate) $)+\mathrm{III}($ arsenite $), 0$ (arsenic), and $-\mathrm{III}($ arsine $))$, and in different forms, such as inorganic (arsenous acid, arsenite, arsenic acids or arsenate), organic (MMAA, DMAA, trimethylarsine oxide, etc.), biological (arsenobetaine, arsenocholine, glycerophosphatidylarsenocholine, etc.), and others (Ng, 2005, Rahman and Hasegawa, 2011). Arsenic is very sensitive to mobilizing at $\mathrm{pH}$ 6.5-8.5 (typically found in ground water) in both oxidizing and reducing conditions. Inorganic forms of As are mainly found in natural waters as oxyanions of trivalent arsenite (As(III)) or pentavalent arsenate $(\mathrm{As}(\mathrm{V}))$, but organic As may be produced by biological activity (bacteria, yeasts, and algae), mostly in surface waters. However, organic forms may also occur where waters are significantly impacted by industrial pollution (Smedley and Kinniburgh, 2003). In oxic seawater, As is typically dominated by $\mathrm{As}(\mathrm{V})$, though some $\mathrm{As}(\mathrm{III})$ is invariably present and becomes increasingly important in anoxic bottom waters. Ratios of $\mathrm{As}(\mathrm{V}) / \mathrm{As}(\mathrm{III})$ are typically in the range of 10 100 in open seawater (Andreae, 1979; Pettine et al., 1992). Increases in organic As species have also been recorded in these zones as a result of methylation reactions by phytoplankton (Cullen and Reimer, 1989). As such, naturally contaminated surface water contains increasing amounts of organic As species. Hasegawa et al. (1997) reported that DMAA and MMAA were the dominant organic As species in Lake Biwa during summer. Application of As-containing herbicides is another source of organic As in the environment. Giacomino et al. (2010) found that over 40\% of As species present in soil were organic, and the remainder were inorganic $\mathrm{As}(\mathrm{V})$ and $\mathrm{As}(\mathrm{III})$. In the southern United States, both inorganic and organic As are found in rice that is now grown in those fields (Rosen et al., 2008). Arsenite (iAsIII) is 
usually more toxic than arsenate (iAsV). Recent studies have shown that MMA(III) and DMA(III) were more acutely toxic and more genotoxic than their parent compounds (Petrick et al., 2000; Mass et al., 2001). These trivalent arsenicals are more toxic than $\mathrm{iAs}(\mathrm{V}), \mathrm{MMA}(\mathrm{V})$, and $\mathrm{DMA}(\mathrm{V})$ in vitro (Styblo et al., 2000; Mass et al., 2001). Recently, LC50 values for human cells were calculated as 571, 843, 5.49, and 2.16 $\mu \mathrm{M}$ for iAsV, DMA(V), iAs(III), and DMA(III), respectively (Naranmandura et al., 2007). This study also showed that dimethylmonothioarsenic (DMMTA(V)) was much more toxic than other pentavalent nonthiolated arsenicals (Naranmandura et al., 2007). Therefore, the daily accumulation of organic As species in oxic water, soil, and plants, as well as food products, is of particular concern. There are several remediation processes of contaminants from the environment. Among them phytoremediation is a well-known ecologically friendly technology and inexpensive alternative, to remediate contaminants from water environment. Uptake and accumulation of inorganic As species by aquatic macrophytes have been studied extensively (Mkandawire and Dudel, 2005); however, few studies have examined the uptake of organic As species. Moreover, arsenate and DMAA are the major As species in oxic aquatic systems (Hasegawa et al., 1999). In our previous study, we found that M. umbrosum could uptake more than 1000 $\mu \mathrm{g} \mathrm{g}^{-1}$ inorganic As (added from sodium arsenite) from the water environment (Islam et al., 2015). Current research focuses on the potential of M. umbrosum to phytofiltrate organic As species from oxic water environments.

\section{Materials and Methods}

\subsection{Plant culture}

Approximately $3 \mathrm{~g}$ (fresh weight) of $M$. umbrosum plants was grown in hydroponic cultures in laboratory conditions for 7 days in a plant growth chamber under controlled environment (14:10 light/dark cycle, $100-125 \mu \mathrm{M} \cdot \mathrm{m}^{-2} \cdot \mathrm{s}^{-1}$ light intensity, $75 \%$ humidity, and $21 \pm 1{ }^{\circ} \mathrm{C}$ temperature). The hydroponic medium contained 200 and $1000 \mu \mathrm{g}$ As $\mathrm{L}^{-1}$ [from MMAA (CH5AsO3) and DMAA (C2H7AsO2)] Milli-Q water (Millipore-Gradient A10, Milli-Q Gradient ZMQG), with 500 mL Hoagland nutrient solution (Hoagland and Arnon, 1950) as a nutrient source. Both pH and redox potential impose important controls on arsenic speciation in the natural environment (Ferguson and Gavis, 1972). Therefore, the solution was maintained at $\mathrm{pH} 7.0$ by adding $\mathrm{KOH}$ or $\mathrm{HCl}$, to retain equal concentrations of $\mathrm{AsO} 2(\mathrm{OH})^{2-}$ and $\mathrm{AsO}(\mathrm{OH})^{2-}$. MMA and DMA are diprotic and monoprotic acids, respectively (Cox and Ghosh, 1994). At a neutral pH, the 
major species of $\mathrm{MMA}(\mathrm{V})$ is $\mathrm{CH} 3 \mathrm{AsO} 2(\mathrm{OH})^{-}$, although the minor species, $\mathrm{CH}_{3} \mathrm{AsO}^{2-}$, will also be present. For DMA(V), both (CH3)2AsO(OH) and (CH3)2AsO ${ }^{2-}$ exist at $\mathrm{pH} 7.0$ (Sharma and Sohn, 2009). All treatments were replicated three times, plus and a control was maintained both for the As and the plant.

2.2 Sample collection, preparation, and chemical analysis

Arsenic status in water samples from each pot was recorded at $24 \mathrm{~h}$ intervals. After 7 days, whole plants were harvested and rinsed with Milli-Q water three times. Whole plants were separated into leaves, stems, and roots for analysis of total As, calcium (Ca), magnesium (Mg), manganese (Mn), and zinc (Zn) content. Leaf, stem, and root samples were air dried on absorbent paper for $24 \mathrm{~h}$ at room temperature. Samples were then oven dried at $65{ }^{\circ} \mathrm{C}$ (Constant Temperature Oven, DKN602, Yamato Scientific Co. Ltd., Japan) for at least $48 \mathrm{~h}$ until they reached a constant weight measured by a digital balance (, HF-200, Max $210 \mathrm{~g}$, $\mathrm{d}=0.001 \mathrm{~g}$; A\&D Co. Ltd, Japan). After grinding the samples, 25-40 mg samples of leaves, stems, or roots were placed individually into $15 \mathrm{~mL}$ polyethylene tubes (Thermo Fisher Scientific, NY, USA). Two $\mathrm{mL}$ of 65\% HNO3 (Wako Pure Chemical Ind. Ltd., Japan) were added, and the samples kept under the fume hood for $12 \mathrm{~h}$. Samples were then covered and digested on a heating block (TAH-2G, Dry Thermo Unit, Japan) at $95{ }^{\circ} \mathrm{C}$ for $2 \mathrm{~h}$. After cooling, $1 \mathrm{~mL}$ of 30\% H2O2 (Wako Pure Chemical Ind. Ltd., Japan) was added and the samples were covered and heated again at $105^{\circ} \mathrm{C}$ for 20 min (Rahman et al., 2007). Digested samples were diluted to $10 \mathrm{~mL}$ with Milli-Q water using $10 \mathrm{~mL}$ volumetric flasks (Pyrex ${ }^{\circledR}$, IWAKI Glass), as described by Cai et al. (2000) and Islam et al. (2013). The diluted samples were then filtered using a $0.45-\mu \mathrm{m}$ syringe-driven filter unit (Millipore, Billerica, USA) and stored in $15 \mathrm{~mL}$ polyethylene bottles. As, Mg, Mn, and Zn contents were measured using an inductively coupled plasmamass spectrophotometer (ICP-MS; Agilent G1820 Model), whereas Ca contents were measured by a flame-type atomic absorption spectrophotometer (AAS; Model 180-80, Hitachi, Japan). The accuracy of the analysis was checked using certified standard reference materials for As (013-15481, Lot ALK 9912, $1000 \mathrm{mg} \mathrm{L}^{-1}$ ), Mn (133-12131, Lot KWR 2425, $1004 \mathrm{mg} \mathrm{L}^{-1}$ ), Zn (264-01421, Lot KWQ 4136, 1005 mg $\mathrm{L}^{-1}$ ), and Mg (136-12121, Lot KWR 2871, $1001 \mathrm{mg} \mathrm{L}^{-1}$ ) obtained from Wako Pure Chemical Ind. Ltd., Japan. Bio-concentration factor (BCF) and root-to-stem and stem-to-leaf translocation factors (TF) were 
also calculated (Snyder, 2006; Gupta et al., 2008) to evaluate phytofiltration ability of M. umbrosum plants.

\subsection{Statistical analysis}

Results were expressed as the means \pm standard error (S.E.) of the three replicates. The degree of significance was calculated using a t-test and curve fitting was applied using Microsoft Excel (Microsoft Office 2007 Professional).

3. Results and discussion

\subsection{Phytofiltration of As from organic sources}

Organic As concentration in the nutrient solution decreased over time. The decreasing trend was significant on the 2nd and 5th days for both MMAA (Fig. 1) and DMAA (only for $0.2 \mu \mathrm{gL}^{-1}$ treatment, Fig. 2b), as M. umbrosum plants can grow when submerged. Whole plants acted as an active site for As absorption as there was no evidence for physiochemical adsorption by the plants or glass pot as described by Robinson et al. (2006). After 7 days of hydroponic culture, M. umbrosum was able to remove approximately $60-75 \%$ As from MMAA (Table 1) and 50-61\% As from DMAA (Table 2). At a lower initial concentration $\left(0.2 \mu \mathrm{g} \mathrm{mL}{ }^{-1}\right), M$. umbrosum removed As from the solution to a final concentration (53 $\mu \mathrm{g} \mathrm{L} \mathrm{L}^{-1}$, Fig. 1b) near the maximum level $\left(50 \mu \mathrm{g} \mathrm{L}^{-1}\right)$ approved by the Bangladesh and China Government Standard (World Bank, 2005). The rate of organic As uptake is lower than inorganic As in the same plant species. Islam et al. (2015) found that M. umbrosum can uptake more than $1000 \mu \mathrm{g} \mathrm{As} \mathrm{g}^{-1}$ from inorganic sodium arsenite. Furthermore, it removed approximately $79.3 \%$ to $89.5 \%$ inorganic As from the solution (Islam et al., 2013). Trivalent methylated arsenic species may be more toxic than inorganic As, as they are more efficient at causing DNA breakdown and lower physiological activity of plants (Vaclavikova et al., 2008).

\subsection{Phytoaccumulation of As within M. umbrosum}

The As phytoaccumulation pattern of M. umbrosum is depicted in Fig. 3. M. umbrosum leaves contain significantly $(\mathrm{P}<0.001)$ higher amounts of As compared to stems and roots for $1 \mu \mathrm{g}$ As $\mathrm{L}^{-1}$ as MMAA or DMAA. However, there were no significant differences between the stems and leaves in As accumulation 
for the $0.2 \mu \mathrm{g} \mathrm{As} \mathrm{L}^{-1}$ treatment (Fig. 3). However, larger amounts of As accumulation were observed in leaves $\left(90 \mu \mathrm{g} \mathrm{g}^{-1}\right)$ and stems $\left.(68 \mu \mathrm{g} \mathrm{g})^{-1}\right)$ treated with MMAA $\left(1 \mu \mathrm{g}\right.$ As $\left.\mathrm{mL}^{-1}\right)$ compared with leaves $(48 \mu \mathrm{g}$ $\left.\mathrm{g}^{-1}\right)$ and stems (28 $\left.\mu \mathrm{g} \mathrm{g}^{-1}\right)$ treated with DMAA $\left(1 \mu \mathrm{g}\right.$ As $\left.\mathrm{mL}^{-1}\right)$ (Fig. 3). These results are consistent with a study by Rahman et al., (2007) that reported accumulation of only $7.65 \pm 0.27 \mathrm{nM}$ As $\mathrm{g}^{-1}$ dry weight in Spirodela polyrhiza exposed to $4.0 \mu \mathrm{M}$ As from DMAA. Furthermore, S. polyrhiza can bioaccumulate 79\% more As from inorganic arsenate than from DMAA. M. umbrosum can also accumulate 10-fold more inorganic As than MMAA and 20-fold more than DMAA (Islam et al., 2015). One reason may be that DMAA has a poor affinity for -SH groups, so that it has an easier transport route to shoots and grain (Meharg et al., 2008), whereas inorganic As uptake mechanisms in M. umbrosum appear to involve -SH groups or protein containing -SH groups.

\subsection{BCF and TF of MMAA and DMAA in M. umbrosum}

BCF provides an index of the ability of the plant to accumulate the metal with respect to the metal concentration in the substrate (Snyder, 2006), whereas TF, or mobilization ratio, determines the relative translocation of metals from the substrate (water or soil) to other parts (root-to-stem-to-leaf) of the plant (Barman et al., 2000; Gupta et al., 2008). BCF, root-to-stem, and stem-to-leaf TF values for various treatments of MMAA and DMAA are given in Tables 1 and 2. BCF values for MMAA and DMAA treatments for different compartments (root, stem, and leaf) of the plant ranged from 21-90 (Table 1) and 9-55 (Table 2), respectively. Higher BCF values indicate the ability of plants to concentrate metal in their tissues (Abhilash et al., 2009). According to Zayed et al. (1998), a plant with a BCF of more than 1000 is considered a hyperaccumulator, a BCF of 1 to less than 1000 an accumulator, and a BCF of less than 1 an excluder. Data from this study show that M. umbrosum is an accumulator for this organic As treatment as all BCF values ranged from 9 to 90 (Tables 1 and 2). Some plant species have shown similar or higher accumulation of inorganic As. Anwar et al. (2006) assessed the exposure and bioavailability of inorganic As using Pteridium aquilinum, Erica australis, Juncus effuses, Phalaris caerulescens, and Spergula arvensis plant species in contaminated soils from the La Parrilla mine, Spain. They reported BCF values of 2.1 to 593.9 for the As contaminated site. Root-to-stem and stem-to-leaf TF values (Tables 1 and 2) were greater than 1 in all cases. As from MMAA and DMAA was readily translocated from root-to-stemto-leaf in oxic aquatic systems, similar to inorganic As species. 
Essential plant macro- (Ca and Mg) and micro- (Mn and $\mathrm{Zn}$ ) nutrient statuses were determined in both MMAA and DMAA treated roots, stems, and leaves after 7 days of the hydroponic experiment (Table 3). Ca content significantly ( $\mathrm{P}<0.01$ and 0.05 ) decreased in leaves and roots, whereas $\mathrm{Mg}$ content increased ( $\mathrm{P}<0.01$ ) in stems for the $1000 \mu \mathrm{g}$ As $\mathrm{L}^{-1}$ (added from MMAA) treatment compared to the control (Table 3). There were no significant changes in macronutrient status in the DMAA treatment. Significant $(\mathrm{P}<$ 0.01 and 0.05) increases in micro-nutrients were observed for MMAA treated roots, stems, and leaves. However, As from DMAA negatively influenced the accumulation of $\mathrm{Zn}(\mathrm{P}<0.05)$ within the plant body, compared with the control (Table 3). In a previous study, we found that Mn content was negatively correlated with added inorganic As; however, the present study showed that M. umbrosum contained increasing amounts of Mn for both MMAA and DMAA treatments. Therefore, there might be different As uptake mechanisms from inorganic and organic sources, as reported by Rahman et al. (2007).

\section{Conclusion}

M. umbrosum was shown as a good As accumulator that can uptake significant amounts of As added from organic sources in oxic aquatic environments. This aquatic plant can reduce As concentration from 750 to $300 \mu \mathrm{g} \mathrm{L} \mathrm{L}^{-1}$ and 200 to $53 \mu \mathrm{g} \mathrm{L} \mathrm{L}^{-1}$, over 7 days in hydroponic conditions, although decreases were slightly

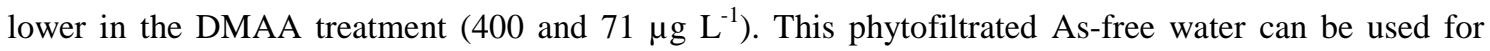
irrigation to prevent As deposition in agricultural crops, as well as for drinking water to reduce As contamination in humans. A previous study showed that $M$. umbrosum is a hyperaccumulator of inorganic As, and is, therefore, a good phytofiltrator for both inorganic and organic As contamination. This plant species can be used as a phytofilter of As contaminated water in small scale rural and urban areas by cultivating it in an aquarium or dish. Further investigations are required to clarify the mechanisms and speciation of As in M. umbrosum for this plant to be used as an effective phytofilter of As from contaminated water.

\section{Conflict of Interest}

The authors declare that there are no conflicts of interest.

\section{Acknowledgement}


The authors thanks to Aqua Friend Hokusui (Hokkaido, Japan) for supply plant materials. This research was financially supported by Global COE Program of Hokkaido University, Ministry of Education, Culture, Sport, Science and Technology (MEXT), Japan.

\section{References:}

Abhilash P. C., Vimal C.P., Srivastava. P, Rakesh P. S., Chandran S., Singh N., Thomas A. P. (2009) Phytofiltration of cadmium from water by Limnocharis flava (L.) Buchenau grown in free-floating culture system. J. Hazard. Mater. 170:791-797.

Anawar H. M., Sanchez A. C., Murciego A., Buyolo T. (2006) Exposure and bioavailability of arsenic in contaminated soils from the La Parrilla mine, Spain. Environ. Geol. 50:170-179.

Andreae, M.O. (1977) Determination of arsenic species in natural waters. Anal. Chem. 49:820-823.

Andreae, M. O. (1979) Arsenic Speciation in Seawater and Interstitial Waters - Influence of BiologicalChemical Interactions on the Chemistry of a Trace-Element. Limnol. Oceanograph. 24(3): 440-452

Barman S. C., Sahu R. K., Bhargava S. K., Chatterjee C. (2000) Distribution of heavy metals in wheat, mustard and weed grains irrigated with industrial effluents. Bull. Environ. Contamin. Toxicol. 64:489_ 496.

Cai Y., Georgiadis M., Fourqurean J.W. (2000) Determination of arsenic in sea grass using inductively coupled plasma mass spectrometry. Spect. Acta Part B. 55, 1411-1422.

Cox C.D., Ghosh M.M. (1994) Surface complexation of methylated arsenates by hydrous oxides. Water Res. 28(5):1181-8.

Cullen W. R., Reimer K. J. (1989) Arsenic speciation in the environment. Chem. Rev. 89:713-764.

Dwivedi A. K. (2013) Arsenic in Groundwater: An Issue Beyond Boundary, In: Rajkumar D, Lal J.K (eds.) Biodiversity Conservation and Sustainable Development Centre for Biological Research, Puthalam, Tamil Nadu, India: 30-43.

Ferguson J.F., Gavis J. (1972) Review of the arsenic cycle in natural waters. Water Res. 6: 1259-74. 
Giacomino A., Malandrino M., Abollino O., Velayutham M., Chinnathangavel T., Mentasti E. (2010) An approach for arsenic in a contaminated soil: Speciation, fractionation, extraction and effluent decontamination, Environmental Pollution, 158, 416-423.

Gupta S., Nayek S., Saha R. N., Satpati S. (2008) Assessment of heavy metal accumulation in macrophyte, agricultural soil and crop plants adjacent to discharge zone of sponge iron factory. Environ. Earth Sci. 55:731-739.

Hasegawa H. (1997) The behavior of trivalent and pentavalent methyl arsenicals in Lake Biwa. Appl. Organomet. Chem. 11:305-311

Hasegawa H., Matsui M., Okamura S., Hojo M., Iwasaki N., Sohrin Y. (1999) Arsenic speciation including ‘Hidden’ arsenic in natural waters. Appl. Organometal. Chem. 13, 113-119.

Hoagland D. R., Arnon D. I., (1950) The Water-culture method for growing plants without soil. Circular. California Agric. Exp. Sta. 347, 32 (2 ${ }^{\text {nd }}$ Ed)

Islam M. S., Saito T., Kurasaki M. (2015) Phytofiltration of arsenic and cadmium using Micranthemum umbrosum: Phytotoxicity, uptake kinetics and mechanism. Ecotoxicol. Environ. Safety 112: 193-200.

Islam M. S., Ueno Y, Sikder M. T., Kurasaki M. (2013) Phytofiltration of Arsenic and Cadmium from the Water Environment Using Micranthemum umbrosum (J.F. Gmel) S.F. Blake as a Hyperaccumulator. Int. J. Phytoremediation 15(10):1010-1021.

Kim K. W., Chanpiwat P., Hanh H. T., Phan K., Sthiannopkao S. (2011) Arsenic geochemistry of groundwater in Southeast Asia. Front Med. 5, 420-433.

Knobeloch L. M., Zierold K. M., Anderson H. A. (2006) Association of arsenic-contaminated drinkingwater with prevalence of skin cancer in Wisconsin’s Fox River Valley. J Health Popul Nutr. 24, 206213.

Ma L. Q., Komar K. M., Tu, C., Zhang W., Cai Y., Kennelley E. D. (2001) A fern that hyperaccumulates arsenic. Nature 409, 579.

Mass M. J., Tennant A., Roop B. C., Cullen W. R., Styblo M., Thomas D. J., Kligermann A. D. (2001) Methylated trivalent arsenic species are genotoxic. Chem. Res. Toxicol. 14:355-361. 
Meharg A. A., Williams P., Deacon C., Adomako E., Lawgali Y., Zhu Y., Raab A., Feldmann J., Carey A., Campbell R., Solaiman A. R. M., Islam R., Hossain S., Sun G. (2008) The risk from arsenic in the food-chain. 20th New Phytologist Symposium, Arsenic: unraveling its metabolism and speciation in plants, Douglas Hotel, Aberdeen, Scotland, UK, 26-27 June, 2008.

Mkandawire M., Dudel E. G. (2005) Accumulation of arsenic in Lemna gibba L. (ducweed) in tailing waters of two abandoned uranium mining sites in Saxony, Germany. Sci. Total Environ. 336, 81-89.

Mohan D., Pittman J.C.U. (2007) Arsenic removal from water/wastewater using adsorbents—a critical review. J. Hazard. Mater. 142:1-53.

Naranmandura H., Ibata K., Suzuki K.T. (2007) Toxicity of dimethylmonothioarsenic acid toward human epidermoid carcinoma A431 cells. Chem. Res. Toxicol. 20:1120-5.

NRC, National Research Council. (1999) Arsenic in Drinking Water. National Academy Press, Washington DC.

Pettine M., Camusso W., Martinotti. (1992) Dissolved and particulate transport of arsenic and chromium in the Po River (Italy). Sci. total environ. 119:253-280.

Petrick J. S., Ayala-Fierro F., Cullen W.R., Carter D.E., Aposhian H.V. (2000) Monomethylarsonous acid (MMAIII) is more toxic than arsenite in change human hepatocytes. Toxicol. App. Pharmacol. 163, 203-207.

Rahman M. A., Hasegawa H. (2011) Review on Aquatic arsenic: Phytoremediation using floating macrophytes. Chemosphere 83, 633-646.

Rahman M. A., Hasegawa H., Ueda K., Maki T., Okumura C., Rahman M.M. (2007) Arsenic accumulation in duckweed (Spirodela polyrhiza L.): A good option for phytoremediation. Chemosphere 69, 493-499.

Robinson B., Kim N., Marchetti M., Moni C., Schroeter L., Dijssel C., Van Den Milne G., Clothier B. (2006) Arsenic hyperaccumulation by aquatic macrophytes in the Taupo Volcanic Zone, New Zealand. Environ. Exper. Bot. 58, 206-215. 
Rosen B. P., Jie Qin, Yoshinaga M. (2008) The arsenic biogeocycle. 20th New Phytologist Symposium, Arsenic: unraveling its metabolism and speciation in plants, Douglas Hotel, Aberdeen, Scotland, UK, 26-27 June, 2008.

Sharma V.K., Sohn M. (2009) Aquatic arsenic: toxicity, speciation, transformation and remediation.

Environ. International, 35:743-759.

Smedley P. L., Kinniburgh D. G. (2003) Source and behavior of arsenic in natural waters, in: Arsenic in drinking water, World Health Organization.

Smedley P. L., Kinniburgh D. G. (2002) A review of the source, behaviour and distribution of arsenic in natural waters. Appl. Geochem. 17: 517-568.

Snyder K. V. W. (2006) Removal of Arsenic from Drinking Water by Water Hyacinths (Eichhornia crassipes). J U S S J W P 1:41-58.

Styblo M., Del Razo L. M., Vega L., Germolec D. R., Edward L., Cluyse L., Hamilton G. A., Reed W., Wang C., Cullen W. R., Thomas D. J. (2000) Comparative toxicity of trivalent and pentavalent inorganic and methylated arsenicals in rat and human cells. Arch. Toxicol. 74: 289-299.

Vaclavikova M., Gallios G. P., Hredzak S., Jakabsky S. (2008) “Removal of arsenic from water streams: an overview of available techniques,” Clean Technol. Environ. Policy, 10, 89-95.

Visoottiviseth, P., Francesconi, K., Sridokchan, W. (2002) The potential of Thai indigenous plant species for the phytoremediation of arsenic contaminated land. Environ. Pollut. 118, 453-461.

World Bank., (2005) Environment and Social Unit-South Asia Region. Towards a More Effective Operational Response. Arsenic Contamination of Groundwater in South and East Asian Countries Volume II Technical Report.

Zayed A., Gowthaman S., Terry N. (1998) Phytoaccumulation of trace elements by wetland plants: 1. Duckweed. Environ. Qual. 27:715-721. 
Zhang X., Lin A. J., Zhao F. J., Xu G. Z., Duan G. L., Zhu Y. G., (2008) Arsenic accumulation by the aquatic fern Azolla: Comparison of arsenate uptake, speciation and efflux by Azolla caroliniana and Azolla filiculoides. Environ. Poll. 156, 1149-1155. 


\section{Captions of Figures}

Fig. 1. As ( $\mu \mathrm{g} \mathrm{L}^{-1}$ ) remaining in water in which M. umbrosum grown with (a) 1.0 and (b) $0.2 \mu \mathrm{g}$ As $\mathrm{mL}^{-1}$ added from MMAA. Error bar indicates mean \pm S.E. $(n=3) . * *$ and $*$ denotes significantly different at $\mathrm{P}<0.01$ and 0.05 , respectively, against for previous days.

Fig. 2 As $\left(\mu \mathrm{g} \mathrm{L}^{-1}\right)$ remaining in water in which M. umbrosum grown with (a) 1.0 and (b) $0.2 \mu \mathrm{g}$ As $\mathrm{mL}^{-1}$ added from DMAA. Error bar indicates mean \pm S.E. $(n=3) . * *$ and * denotes significantly different at $\mathrm{P}<0.01$ and 0.05 , respectively, against for previous days.

Fig. 3. As accumulation ( $\mu \mathrm{g} \mathrm{g}^{-1}$ ) pattern in root, stem and leaf of $M$. umbrosum after seven days exposure to 0.2 and $1.0 \mu \mathrm{g}$ As $\mathrm{mL}^{-1}$ water as (a) MMAA and (b) DMAA. Error bars indicates mean \pm S.E. (n=3). ** and *denotes significantly different at $\mathrm{P}<0.001$ and 0.005 , respectively, against for As from water to root, root to stem and stem to leaf. 


\section{List of Tables}

Table 1. Bio-concentration factor (BCF), root to stem and stem to leaf TF (translocation factor) values and As removal efficiency (\%) of M. umbrosum (n=3) for MMAA treatment.

Table 2. Bio-concentration factor (BCF), root to stem and stem to leaf TF (translocation factor) values and As removal efficiency (\%) of $M$. umbrosum (n=3) for DMAA treatment.

Table 3. Composition of nutrient elements (oven dry basis) of Micranthemum umbrosum plant parts grown in $1000 \mu \mathrm{g} \mathrm{L}^{-1}$ As (from MMAA and DMAA) tainted water 


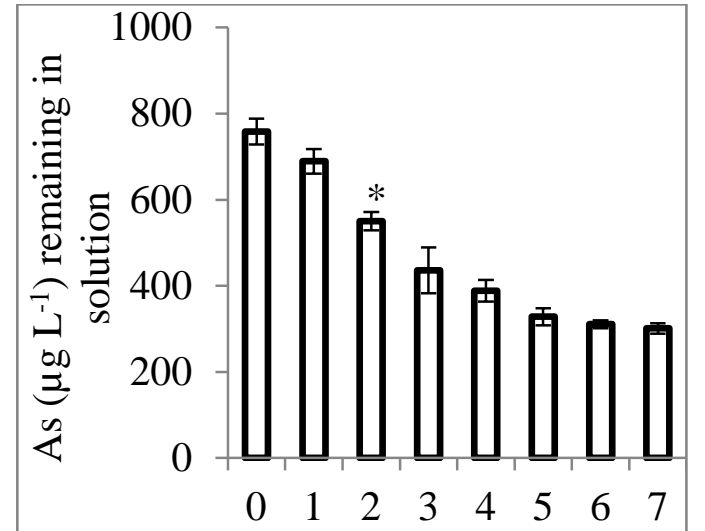

(a)
Days

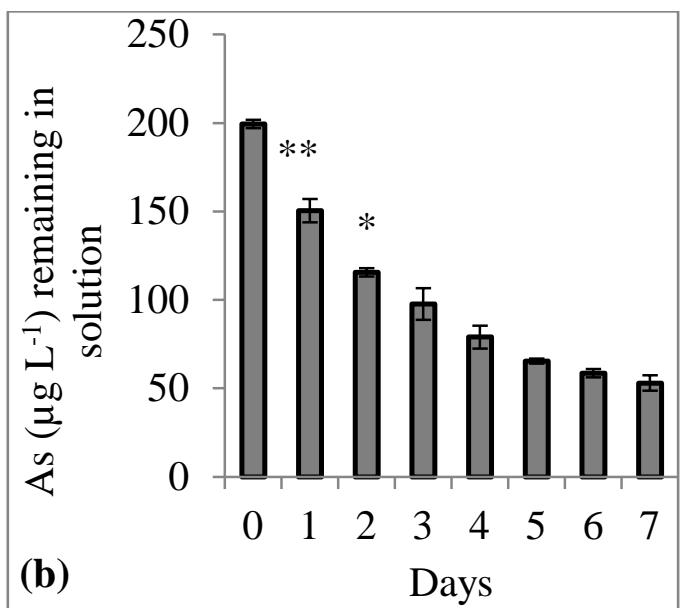

Days

Fig. 1. As ( $\mu g \mathrm{~L}^{-1}$ ) remaining in water in which M. umbrosum grown with (a) 1.0 and (b) $0.2 \mu g \mathrm{As} \mathrm{mL}^{-1}$ added from MMAA. Error bar indicates mean \pm S.E. $(n=3)$. ${ }^{* *}$ and * denotes significantly different at $\mathrm{P}<0.01$ and 0.05 , respectively, against for previous days. 

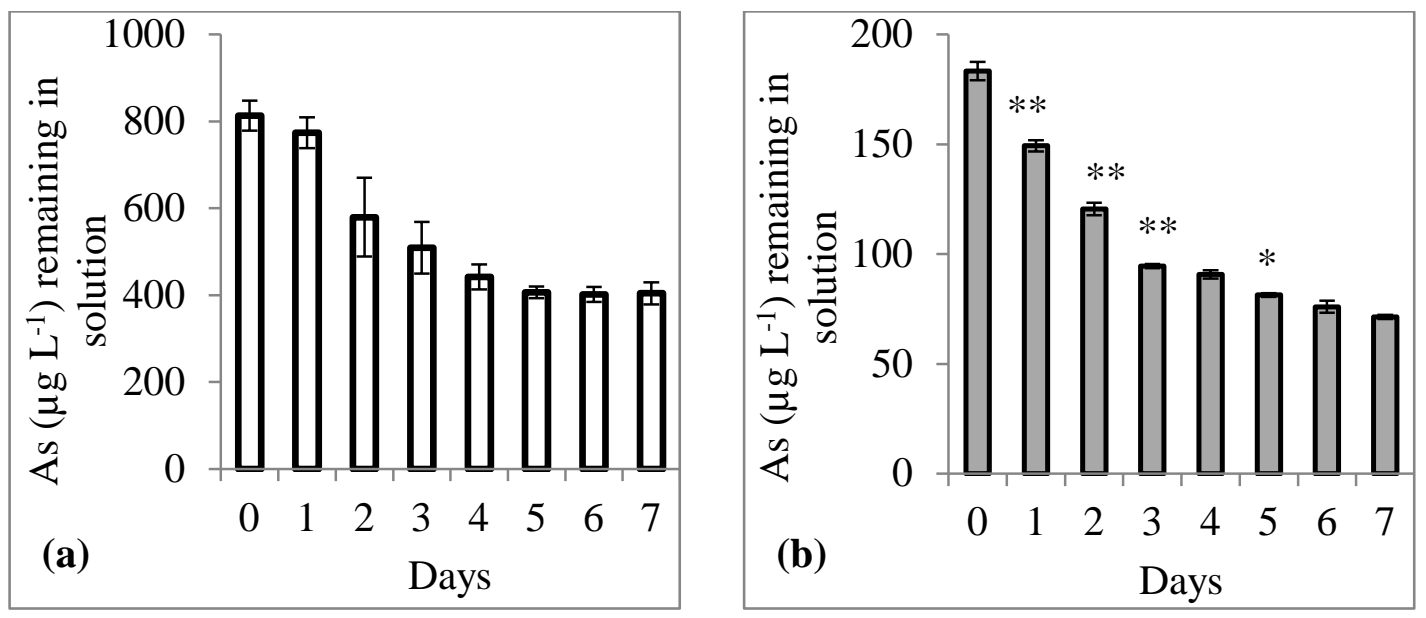

Fig. 2. As ( $\mu \mathrm{g} \mathrm{L}^{-1}$ ) remaining in water in which $M$. umbrosum grown with (a) 1.0 and (b) $0.2 \mu g \mathrm{As} \mathrm{mL}^{-1}$ added from DMAA. Error bar indicates mean \pm S.E. $(n=3)$. ** and * denotes significantly different at $\mathrm{P}<0.01$ and 0.05 , respectively, against for previous days. 

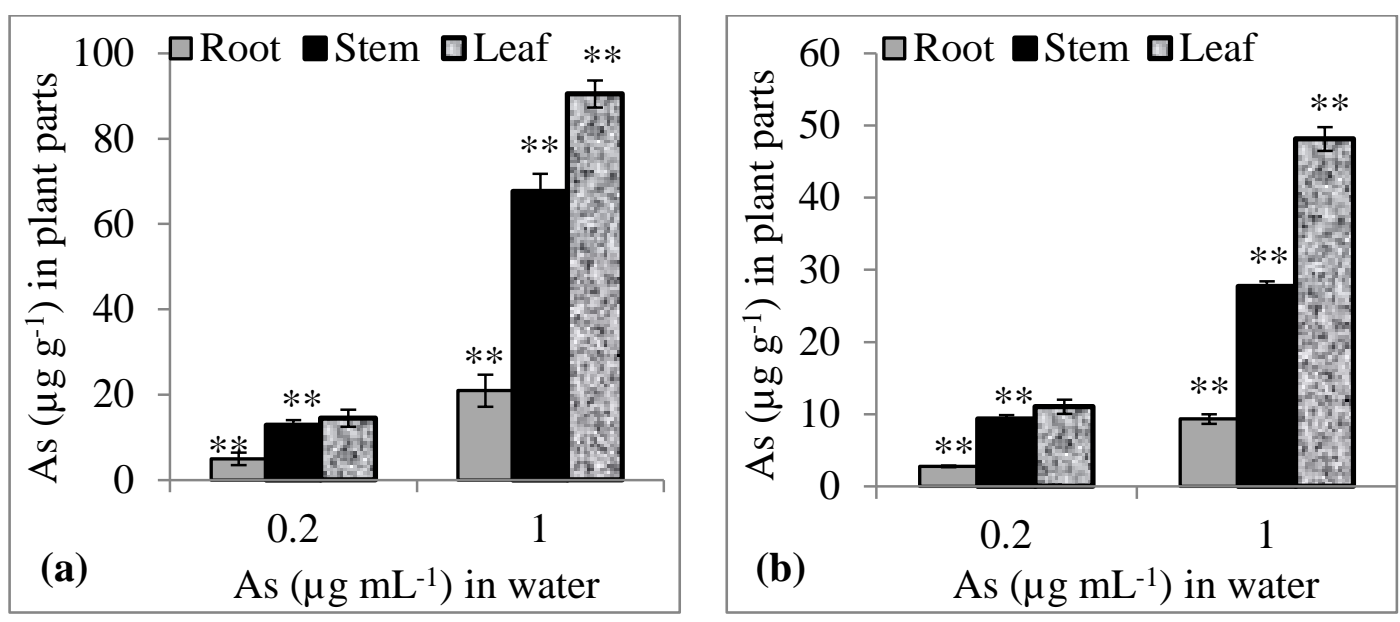

Fig. 3. As accumulation ( $\mu \mathrm{g} \mathrm{g}^{-1}$ ) pattern in root, stem and leaf of $M$. umbrosum after seven days exposure to 0.2 and $1.0 \mu \mathrm{g}$ As $\mathrm{mL}^{-1}$ water as (a) MMAA and (b) DMAA. Error bars indicates mean \pm S.E. $(\mathrm{n}=3)$. ** and *denotes significantly different at $\mathrm{P}<0.001$ and 0.005 , respectively, against for As from water to root, root to stem and stem to leaf. 
Table 1. Bio-concentration factor (BCF), root to stem and stem to leaf TF (translocation factor) values and As removal efficiency (\%) of M. umbrosum (n=3) for MMAA treatment.

\begin{tabular}{|c|c|c|c|c|}
\hline $\begin{array}{c}\text { Conc. of As } \\
\left(\mu g \mathrm{~mL}^{-1}\right)\end{array}$ & Plant parts & $\begin{array}{c}\text { BCF } \\
{[\text { Mean } \pm \text { S.E. }]}\end{array}$ & $\mathrm{TF}$ & \% Removed \\
\hline \multirow{3}{*}{0.2} & Root & $25 \pm 7.2$ & & \multirow{3}{*}{75} \\
\hline & Stem & $64 \pm 5.8$ & 2.6 & \\
\hline & Leaf & $72 \pm 9.8$ & 1.1 & \\
\hline \multirow{3}{*}{1} & Root & $21 \pm 3.8$ & & \multirow{3}{*}{60} \\
\hline & Stem & $68 \pm 4.1$ & 3.2 & \\
\hline & Leaf & $90 \pm 3.2$ & 1.3 & \\
\hline
\end{tabular}


Table 2. Bio-concentration factor (BCF), root to stem and stem to leaf TF (translocation factor) values and As removal efficiency (\%) of M. umbrosum (n=3) for DMAA treatment.

\begin{tabular}{|c|c|c|c|c|}
\hline $\begin{array}{c}\text { Conc. of As } \\
\left(\mu g \mathrm{~mL}^{-1}\right)\end{array}$ & Plant parts & $\begin{array}{c}\text { BCF } \\
\text { [Mean } \pm \text { S.E.] }\end{array}$ & $\mathrm{TF}$ & \% Removed \\
\hline \multirow{3}{*}{0.2} & Root & $14 \pm 0.7$ & & \multirow{3}{*}{61} \\
\hline & Stem & $47 \pm 2.7$ & 3.4 & \\
\hline & Leaf & $55 \pm 5.0$ & 1.2 & \\
\hline \multirow{3}{*}{1} & Root & $09 \pm 0.7$ & & \multirow{3}{*}{50} \\
\hline & Stem & $28 \pm 0.7$ & 3.0 & \\
\hline & Leaf & $48 \pm 1.7$ & 1.7 & \\
\hline
\end{tabular}


Table 3. Composition of nutrient elements (oven dry basis) of M. umbrosum plant parts grown in 1000 $\mu \mathrm{g} \mathrm{L}^{-1}$ As (from MMAA and DMAA) tainted water

\begin{tabular}{|c|c|c|c|c|c|c|}
\hline $\begin{array}{c}\text { Source } \\
\text { of As }\end{array}$ & $\begin{array}{c}\text { Dose } \\
(\mu g \\
\left.L^{-1}\right)\end{array}$ & $\begin{array}{l}\text { Plant } \\
\text { parts }\end{array}$ & $\begin{array}{c}\mathrm{Ca} \\
\left(\mathrm{mg} \mathrm{g}^{-1}\right)\end{array}$ & $\begin{array}{c}\mathrm{Mg} \\
\left(\mu g g^{-1}\right)\end{array}$ & $\begin{array}{c}\mathrm{Mn} \\
\left(\mu g g^{-1}\right)\end{array}$ & $\begin{array}{c}\mathrm{Zn} \\
\left(\mu \mathrm{g} \mathrm{g}^{-1}\right)\end{array}$ \\
\hline \multirow{3}{*}{ Control } & \multirow{3}{*}{0} & Leaf & $3.54 \pm 0.10$ & $22.66 \pm 0.37$ & $225.09 \pm 8.32$ & $82.57 \pm 1.46$ \\
\hline & & Stem & $2.89 \pm 0.15$ & $18.03 \pm 1.11$ & $120.05 \pm 3.94$ & $39.26 \pm 1.88$ \\
\hline & & Root & $3.94 \pm 0.08$ & $4.87 \pm 1.62$ & $93.98 \pm 5.65$ & $37.94 \pm 1.19$ \\
\hline \multirow{3}{*}{ MMAA } & \multirow{3}{*}{1000} & Leaf & $* 2.99 \pm 0.09$ & $30.66 \pm 2.61$ & *269.14 46.00 & *123.34 \pm 5.23 \\
\hline & & Stem & $3.16 \pm 0.20$ & $* * 26.95 \pm 1.07$ & $* * 184.97 \pm 3.91$ & $* * 81.26 \pm 5.29$ \\
\hline & & Root & $* * 2.81 \pm 0.19$ & $4.99 \pm 0.97$ & $* * 278.65 \pm 4.56$ & $* * 125.12 \pm 4.28$ \\
\hline \multirow{3}{*}{ DMAA } & \multirow{3}{*}{1000} & Leaf & $4.01 \pm 0.27$ & $31.76 \pm 2.64$ & $* * 121.32 \pm 5.34$ & 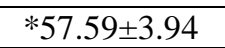 \\
\hline & & Stem & $3.32 \pm 0.26$ & $22.72 \pm 0.69$ & $105.01 \pm 4.21$ & $28.30 \pm 3.71$ \\
\hline & & Root & $3.98 \pm 0.91$ & $2.66 \pm 0.36$ & $* * 289.54 \pm 9.29$ & $* 23.17 \pm 3.62$ \\
\hline
\end{tabular}

Each value indicated as Mean \pm S.E. $(\mathrm{n}=3)$; ** and * showed significantly difference against control or 0 $\left(\mu \mathrm{g} \mathrm{L}^{-1}\right)$ at $\mathrm{p}<0.01$ and 0.05 , respectively. 